\title{
Screening Children for Family Violence: A Review of the Evidence for the US Preventive Services Task Force
}

Peggy Nygren, $M A^{1}$

Heidi D. Nelson, MD, MPH ${ }^{1,2}$

Jonathan Klein $M D, M P H^{3}$

'The Oregon Evidence-based Practice Center, Department of Medical Informatics and Clinical Epidemiology, Oregon Health \& Science University, Portland, Ore

${ }^{2}$ Medical Service, Veterans Affairs Medical Center, Portland, Ore

${ }^{3}$ Department of Pediatrics, University of Rochester, Rochester, NY

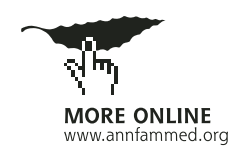

Conflicts of interest: none reported

\section{CORRESPONDING AUTHOR:}

Heidi D. Nelson, MD, MPH

Oregon Health \& Science University

Mail Code BICC 504

3181 SW Sam Jackson Park Road

Portland, OR 97201

nelsonh@ohsu.edu.

\begin{abstract}
BACKGROUND We wanted to evaluate the benefits and harms of screening children in primary health care settings for abuse and neglect resulting from family violence by examining the evidence on the performance of screening instruments and the effectiveness of interventions.

METHODS We searched for relevant studies in MEDLINE, PsycINFO, CINAHL, ERIC, Cochrane Controlled Trials Register, and reference lists. English language abstracts with original data about family violence against children focusing on screening and interventions initiated or based in health care settings were included. We extracted selected information about study design, patient populations and settings, methods of assessment or intervention, and outcome measures, and applied a set of criteria to evaluate study quality.
\end{abstract}

RESULTS All instruments designed to screen for child abuse and neglect were directed to parents, particularly pregnant women. These instruments had fairly high sensitivity but low specificity when administered in high-risk study populations and have not been widely tested in other populations. Randomized controlled trials of frequent nurse home visitation programs beginning during pregnancy that address behavioral and psychological factors indicated improved abuse measures and outcomes. No studies were identified about interventions in older children or harms associated with screening and intervention.

CONCLUSIONS No trials of the effectiveness of screening in a health care setting have been published. Clinician referrals to nurse home visitation during pregnancy and in early childhood may reduce abuse in selected populations. There are no studies about harms of screening and interventions.

Ann Fam Med 2004;2:161-169. DOI: 10.1370/afm.113.

\section{INTRODUCTION}

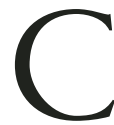
hild abuse and neglect has been defined as "any recent act or failure to act on the part of a parent or caretaker which results death, serious physical or emotional harm, sexual abuse or exploitation, or an act or failure to act which presents an imminent risk of serious harm." ${ }^{11}$ Approximately 1 million children are identified as abused in the United States each year. ${ }^{2}$ In 1999, reported abuse rates were 1,180 per 100,000 children with the highest rates for children age 3 years and younger. ${ }^{3}$ An estimated 1,100 children died of abuse and neglect that year, approximately 1.62 deaths per 100,000 children. ${ }^{3}$ Reported abuse likely captures only a fraction of all cases. ${ }^{4} \mathrm{~A}$ large survey of adults indicated that $11 \%$ experienced psychological abuse, $11 \%$ physical abuse, and $22 \%$ sexual abuse during childhood. ${ }^{5}$

Frequently cited factors associated with child abuse and neglect include low income, ${ }^{6-9}$ low maternal education, ${ }^{6-8}$ nonwhite ethnicity, ${ }^{6,9}$ large family 
size ${ }_{1}^{6,8}$ young age of the mother ${ }^{6}$ single-parent status ${ }_{1}{ }^{6}$ parental psychiatric disturbance, ${ }^{10}$ and presence of a stepfather, ${ }^{6}$ among others. ${ }^{6,11}$ As the number of risk factors increases, the proportion of children maltreated also increases. ${ }^{6}$

Many health problems are associated with abuse and neglect. These problems include acute trauma, including death, unwanted pregnancy, and long-term physical and mental problems, such as depression, posttraumatic stress disorder, somatization, suicide, and substance abuse. ${ }^{5,12-21}$ Children who witness intimate partner violence are at risk for developmental delay, school failure, and a variety of psychiatric disorders including depression and oppositional defiant disorder, ${ }_{1}^{22,23}$ and violence against others. ${ }^{24}$ Children experiencing sexual or physical abuse have a higher risk of intimate partner abuse as adults. ${ }^{25-28}$

The clinician's role in identification and intervention is considered a professional responsibility by physician and nursing organizations. ${ }^{29,30}$ Ongoing child abuse is evidenced as multiple and recurrent injuries, injury histories inconsistent with physical findings, and injuries inconsistent with children's abilities to sustain them on their own. Identification and reporting of abuse are inconsistent and highly dependent on the clinician's awareness and training. Reporting child abuse to protective services is mandatory in almost all states, although statutes mandating reporting vary. Nineteen states require that any person who suspects child abuse or neglect must report ${ }_{i}$ the majority of states limit mandatory reporting to professionals working with children. ${ }^{31}$ Hospitals are also required to address abuse for accreditation. ${ }^{32}$
Many children experiencing abuse do not show obvious evidence of abuse. Whether screening all children leads to a decline in abuse is unknown, protocols for screening are lacking, and few clinicians routinely screen patients who do not have apparent injuries. ${ }^{33-38}$ The evidence for how to intervene effectively once problems are identified is limited.

In 1996, the US Preventive Services Task Force (USPSTF) concluded that there was insufficient evidence to recommend for or against the use of specific screening instruments to detect family violence for children, but it recommended that clinicians ask questions about abuse if it is suspected. ${ }^{39}$ This report is an update on the current literature on family violence focusing on studies of the performance of screening instruments designed for the health care setting and the effectiveness of clinical-based interventions for children. A separate report on screening for family violence in women and elderly adults is available elsewhere. ${ }^{40}$

\section{METHODS}

The analytic framework and key questions guiding this systematic review are detailed in Figure 1. Relevant studies were identified from multiple searches of MEDLINE (1966 to December 2002), PsycINFO (1984 to December 2002), CINAHL (1982 to December 2002), ERIC (1989 to December 2002), and the Cochrane Controlled Trials Register (search strategies are available as supplemental data in Appendix 1, which can be found online at http://www. annfammed.org/cgi/content/full/2/2/161/DC1).

\section{Figure 1. Analytic framework and key questions.}

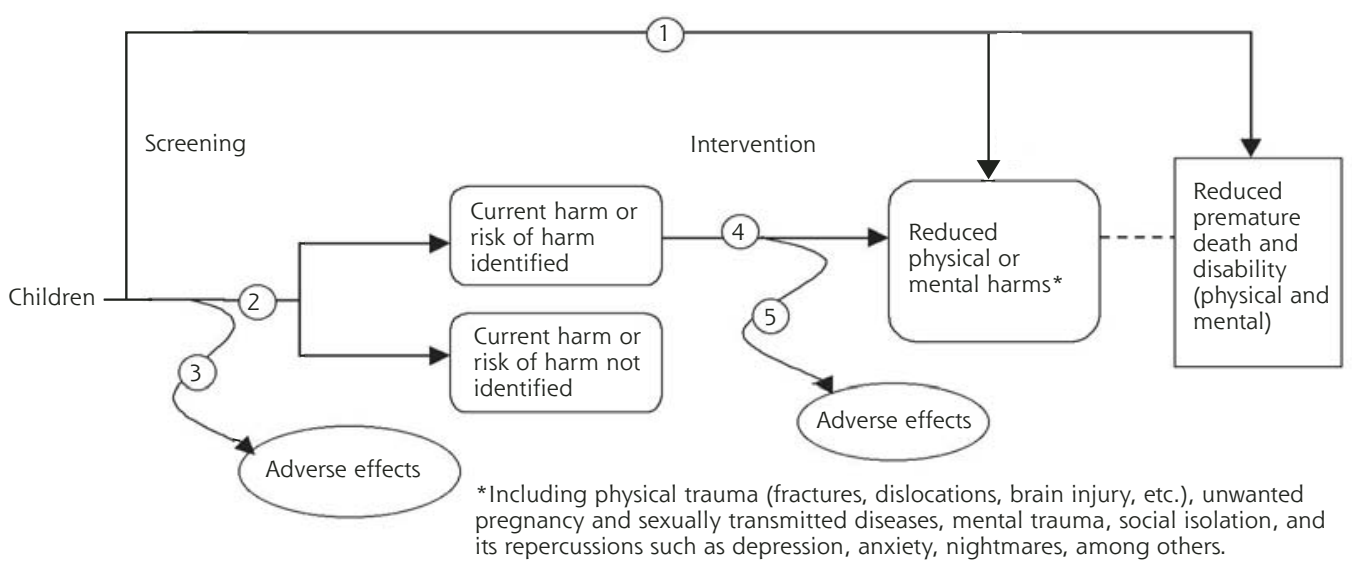

Key questions

Arrow 1: Does screening for family violence reduce harm and premature death and disability?

Arrow 2: How well does screening identify current harm or risk of harm from family violence?

Arrow 3: What are the adverse effects of screening?

Arrow 4: How well do interventions reduce harm from family violence?

Arrow 5: What are the adverse effects of intervention? 
We reviewed references listed in a review of early childhood home visitation for the prevention of violence for the US Task Force on Community Prevention Service, ${ }^{41}$ the Prevention of Child Maltreatment Update from the Canadian Task Force on Preventive Health Care, ${ }^{42}$ and Violence in Families: Assessing Prevention and Treatment Programs. ${ }^{43}$ Additional articles were obtained by reviewing reference lists of pertinent studies, reviews, and editorials, and by consulting experts.

We defined screening as assessment of current harm or risk of harm from family violence in asymptomatic persons in a health care setting. Universal screening means assessing everyone; selective screening indicates only those who meet specific criteria are assessed. The target population for this review was children as victims of abuse or neglect directed toward them by family members, caretakers, or others with similar relationships.

Studies included in this review had English-language abstracts, were applicable to US clinical practice, described abuse and neglect against children, were conducted in or linked to primary care (family practice, pediatrics), obstetrics and gynecology, or emergency department settings, and included a physician or other health provider in the process of assessment or intervention. We excluded studies about patients with trauma.

Studies about assessment were included if they evaluated the performance of verbal or written questionnaires or other assessment procedures, such as physical examinations, that were brief and applicable to the primary care setting. Included studies described the study sample, the screening instrument or procedure, the abuse or neglect outcome, and the collection of data. Outcomes included indicators of physical abuse, neglect, emotional abuse or sexual abuse, and any reported related health outcomes (ie, depression).

Studies about interventions were included if they measured the effectiveness of an intervention in reducing harm from family violence compared wth comparison groups. We excluded studies that tested effectiveness of interventions to educate health care professionals about family violence or to increase screening rates in institutions. We also excluded studies about mandatory reporting laws, descriptions of programs, the accuracy of physician diagnosis and reporting of abuse, and physician factors related to reporting.

From each included study, we abstracted the study design, number of participants, setting, length and type of interventions, length of follow-up, outcomes, methods of outcome measurement, and study duration, among others. Two reviewers independently rated the quality of each study using criteria specific to different study designs developed by the USPSTF (study qual- ity rating criteria are available as supplemental data in Appendix 2, which can be found online at http://www.annfammed.org/cgi/content/full/2/ 2/161/DC2). When reviewers disagreed, a final score was reached through consensus.

\section{RESULTS}

\section{Screening}

We identified and reviewed 1,808 abstracts and retrieved 65 articles for further review. Six studies met eligibility criteria. Additional details of these studies are provided in Table $1,{ }^{44-50}$ and as supplemental data in Appendix 3, ${ }^{44-68}$ which can be found online at http://www.annfammed.org/cgi/content/full/2/2/ 161/DC3.

No studies meeting eligibility criteria directly addressed the effectiveness of screening in reducing harm and premature death and disability. A limited number of studies described the performance of screening methods, such as self-administered questionnaires, clinical staff-directed interviews, and clinical observation. All studies primarily assessed parents, rather than children directly, and none utilized specific physical examination protocols for screening. Instruments and scoring procedures included in these studies are described in Appendix 4, 49,51-53 which can be found online as supplemental data at http://www.ann fammed.org/cgi/content/full/2/2/161/DC4.

Few studies evaluated the performance of these approaches in predicting child abuse and neglect outcomes. Screening instruments had fairly high sensitivity but low specificity when administered in the study populations. Best results were achieved when screening

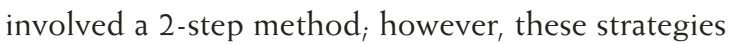
have not been widely tested in other populations and have not been evaluated for feasibility in the primary care setting.

\section{Self-administered Questionnaires}

The Kempe Family Stress Inventory $(\mathrm{KFI})^{53}$ was used in 3 studies meeting eligibility criteria (Table 1).44-47,52 Study populations included predominantly young, single women with low socioeconomic indicators. A retrospective cohort study found that a high score on the KFI was the only statistically significant predictor of maltreatment at 1 and 2 years and, when compared with a low score, was associated with more clinic visits during the first year and hospital admissions during the first 6 months. ${ }^{44}$ Other studies used the KFI in a 2 -step screening process that began with the 15 -item Hawaii Risk Indicators Screening Tool. ${ }^{45-47,52}$ The 2-step process had $89 \%$ sensitivity and $28 \%$ specificity when 
compared with responses on the Child Abuse Potential (CAP) inventory, a 160-item instrument, ${ }^{45,46,52}$ and $97 \%$ sensitivity and $21 \%$ specificity when compared with maltreatment rates in another study. ${ }^{47,52}$

\section{Clinical Staff-administered Questionnaires}

The Maternal History Interview (MHI-2) utilizes openended questions and subscales to evaluate parenting skills, personality, discipline philosophy, life stress,

\section{Table 1. Studies of Child Abuse Screening Instruments}

\begin{tabular}{|c|c|c|c|c|c|}
\hline $\begin{array}{l}\text { Author, } \\
\text { Year }\end{array}$ & No. & Population and Settings & Instruments & Results & $\begin{array}{l}\text { Quality Rating } \\
\text { and Limitations }\end{array}$ \\
\hline \multicolumn{6}{|c|}{ Self-administered questionnaires } \\
\hline $\begin{array}{l}\text { Stevens - } \\
\text { Simon, } \\
2001^{44}\end{array}$ & 262 & $\begin{array}{l}\text { Adolescents ( } 13-19 \text { y) in a } \\
\text { maternity program at the } \\
\text { University of Colorado } \\
\text { Hospital In Denver ( } 32 \% \\
\text { African American, } 22 \% \\
\text { Hispanic, } 92 \% \text { Medicaid } \\
\text { recipients, } 94 \% \text { unmarried) }\end{array}$ & $\begin{array}{l}\text { Kempe Family Stress } \\
\text { Inventory (KFI) }\end{array}$ & $\begin{array}{l}\text { At } 1 \text { and } 2 \text { years, the } \mathrm{KFI} \text { was } \\
\text { the only significant predictor } \\
\text { of maltreatment using } \\
\text { multiple outcome measures } \\
\text { (RR } 8.41,95 \% \mathrm{Cl}, 5.77-10 \text {; } \\
\text { RR } 5.19,95 \% \mathrm{Cl}, 1.99- \\
13.60 \text { ) }\end{array}$ & $\begin{array}{l}\text { Good-fair } \\
\text { Differential loss to } \\
\text { follow-up }\end{array}$ \\
\hline $\begin{array}{l}\text { CCAPR } \\
1996^{45,46}\end{array}$ & 287 & $\begin{array}{l}\text { Pregnant women at hospital } \\
\text { obstetric clinics in } 6 \text { counties } \\
\text { in Oahu (Hawaii Healthy } \\
\text { Start) (mean age } 23 \text { y, 65\% } \\
\text { poor, } 89 \% \text { multicultural, } \\
40 \% \text { poor maternal mental } \\
\text { health, } 45 \% \text { domestic } \\
\text { violence in the home, 30\% } \\
\text { parental substance use, } 28 \% \\
\text { no high school diploma) }\end{array}$ & $\begin{array}{l}2 \text { step screening: } \\
\text { 1. } 15 \text { item Hawaii Risk } \\
\text { Indicators Screening } \\
\text { Tool (medical record } \\
\text { or interview) } \\
\text { 2. } \mathrm{KFI}\end{array}$ & $\begin{array}{l}89 \% \text { sensitivity and } 28 \% \\
\text { specificity with high scores } \\
\text { on the Child Abuse Potential } \\
\text { (CAP) inventory }\end{array}$ & $\begin{array}{l}\text { Fair } \\
\text { No abuse outcomes, } \\
\text { high attrition }\end{array}$ \\
\hline $\begin{array}{l}\text { Katzev, } \\
1997^{47}\end{array}$ & 2,870 & $\begin{array}{l}\text { At-risk pregnant women from } \\
12 \text { counties in Oregon } \\
\text { (Healthy Families) ( } 72 \% \\
\text { single parents, } 68 \% \text { with story } \\
\text { of child abuse or neglect, } \\
57 \% \text { less than high school } \\
\text { education, } 37 \% \text { history } \\
\text { of substance abuse, } 29 \% \\
17 \text { y or younger) }\end{array}$ & $\begin{array}{l}2 \text { step screening: } \\
\text { 1. } 15 \text { item Hawaii Risk } \\
\text { Indicators Screening } \\
\text { Tool (medical record } \\
\text { or interview) } \\
\text { 2. If positive then, KFI }\end{array}$ & $\begin{array}{l}\text { 1,350 were given the } \mathrm{KFI} \text {. } \\
\text { Score was highly correlated } \\
\text { with maltreatment rates (per } \\
1000 \text { children): } 7 \text { for low-risk } \\
\text { scores, } 18 \text { moderate, } 45 \text { high, } \\
\text { and } 172 \text { severe. Korfmacher } \\
\text { reports sensitivity } 97 \% \text {, } \\
\text { specificity } 21 \% \text { for scores in } \\
\text { high-severe risk range }\end{array}$ & $\begin{array}{l}\text { Fair-poor } \\
\text { Many confirmed } \\
\text { reports were made } \\
\text { by home visitors to } \\
\text { high-risk homes }\end{array}$ \\
\hline \multicolumn{6}{|c|}{ Clinical staff-administered questionnaires } \\
\hline $\begin{array}{l}\text { Brayden, } \\
1993^{48}\end{array}$ & 1,089 & $\begin{array}{l}\text { Pregnant women receiving } \\
\text { prenatal care at Metropolitan } \\
\text { Nashville General Hospital, } \\
\text { Tennessee ( }<23 \text { y, } 60 \% \\
\text { single, } 68 \% \text { white, } 25 \% \\
\text { unemployed) }\end{array}$ & $\begin{array}{l}\text { Maternal History } \\
\text { Interview-2, open- } \\
\text { ended questions, and } \\
\text { subscales including } \\
\text { parenting skills, } \\
\text { personality, discipline } \\
\text { philosophy, life stress, } \\
\text { and others; high risk } \\
\text { based on percentile } \\
\text { scoring on subscales; } \\
314 \text { identified as high } \\
\text { risk }\end{array}$ & $\begin{array}{l}\text { The Maternal History Inteview- } 2 \\
\text { predicted child abuse, but not } \\
\text { neglect or sexual abuse. High- } \\
\text { risk group } 6.6 \% \text { with child } \\
\text { abuse reports compared with } \\
2.3 \% \text { in low-risk group in first } \\
36 \text { months (RR } 3.02,95 \% \mathrm{Cl} \text {, } \\
1.02-8.90 \text { ) }\end{array}$ & $\begin{array}{l}\text { Poor } \\
\text { Participation was } \\
\text { low; requires } \\
\text { trained interviewers }\end{array}$ \\
\hline $\begin{array}{l}\text { Anderson, } \\
1993^{49}\end{array}$ & 185 & $\begin{array}{l}\text { Abusive and nonabusive } \\
\text { mothers recruited from a } \\
\text { national sample of female } \\
\text { nurses contacted through } \\
\text { advertising and a mailing } \\
\text { list }\end{array}$ & $\begin{array}{l}\text { Parenting Profile } \\
\text { Assessment, } 21 \text {-item } \\
\text { nurse interview for the } \\
\text { primary care setting; } \\
38(21 \%) \text { scored as } \\
\text { high risk }\end{array}$ & $\begin{array}{l}75 \% \text { sensitivity, } 86 \% \text { specificity } \\
\text { for self-reported abuse. Most } \\
\text { sensitive to high stress and } \\
\text { poor marital relationships }\end{array}$ & $\begin{array}{l}\text { Poor } \\
\text { Only self-reports of } \\
\text { abuse by mothers, } \\
\text { no actual abuse } \\
\text { measured or } \\
\text { verified; small } \\
\text { sample with only } \\
15 \text { self-reported } \\
\text { abusers }\end{array}$ \\
\hline \multicolumn{6}{|c|}{ Clinician observation } \\
\hline $\begin{array}{l}\text { Leventhal, } \\
1996^{50}\end{array}$ & $\begin{array}{l}114 \text { cases } \\
114 \\
\text { controls }\end{array}$ & $\begin{array}{l}\text { Children at the Primary Care } \\
\text { Center at Yale New Haven } \\
\text { Hospital referred to the } \\
\text { hospital's child abuse } \\
\text { committee from the } \\
\text { postpartum ward by } \\
\text { clinicians }\end{array}$ & $\begin{array}{l}\text { Clinician judgment of } \\
\text { potential child abuse } \\
\text { or neglect based on a } \\
\text { number of criteria } \\
\text { including parental } \\
\text { substance use, income, } \\
\text { social support, previous } \\
\text { child abuse or neglect, } \\
\text { and parenting behavior }\end{array}$ & $\begin{array}{l}\text { After controlling for baseline } \\
\text { variables, } 1.8 \text {-fold increase } \\
\text { in the rate of subsequent } \\
\text { hospitalizations of the } \\
\text { high-risk children compared } \\
\text { with others }(P<.05)\end{array}$ & $\begin{array}{l}\text { Poor } \\
\text { Risk criteria not } \\
\text { fully defined or } \\
\text { standardized }\end{array}$ \\
\hline
\end{tabular}


and others to determine risk for child abuse. ${ }^{48}$ Mothers determined to be high-risk by the MHI-2 had a higher incidence of reported child abuse than low-risk mothers in a study of young pregnant women. ${ }^{48}$ The Parenting Profile Assessment (PPA) is a 21 -item nurse interview designed for the primary care setting. ${ }^{49}$

Responses on the PPA were compared with self-reports about past episodes and indicated $75 \%$ sensitivity and $86 \%$ specificity. ${ }^{49}$

\section{Other Techniques: Clinician Observation}

In a retrospective cohort study, nurses referred patients and their newborns to the hospital's child abuse committee from the postpartum unit after determining them to be at high risk for abuse based on a number of nonstandardized criteria. ${ }^{50}$ When compared with low-risk patients, high-risk patients had a significantly greater rate of subsequent hospitalizations for medical and psychosocial reasons.

\section{Interventions}

We found and reviewed 1,748 abstracts. Seventeen studies, utilizing 13 unique populations, met inclusion criteria, ${ }^{47,48,54-68}$ including 9 randomized controlled trials. All studies evaluated interventions for pregnant and postpartum women and their infants and are described in Table $2^{47,48,54-68}$ and Appendix $3^{44-68}$ (http: //www.annfammed.org/cgi/content/full/2/2/161/DC3).

A randomized controlled trial with a 15 -year follow-up indicated that nurse home visits during the prenatal period and for 2-years postpartum for low-income women can improve short-term and long-term abuse and neglect outcomes for children. ${ }^{54-58}$ Nurse visits included parent education, support systems for the mother, and engagement of family members with other health and social services. Results at 2 years showed that high-risk women who had nurse visits were less likely to commit acts of child abuse and neglect than high-risk women without visits $(P=.07) .{ }^{57}$ At 3 - and 4-year follow-up observations, there were no differences between groups for child abuse and neglect outcomes. ${ }^{54,55}$ At the 15 -year follow-up, children in the nurse-visited group were less likely to have reports of child maltreatment of any kind $(P<.05) .{ }^{58}$ Mothers in the nurse-visited group were less likely to be perpetrators of child abuse and neglect than mothers without nurse visits 15 years after the intervention $(P<.001){ }^{56}$

Six trials of fair quality evaluated home visitation programs linked to prenatal clinics or hospital care..$^{59-64}$ Studies varied in the types and duration of interventions. All but 1 study $^{62}$ used inclusion criteria based on an assessment of risk for child abuse and neglect, although no study used standardized or validated instruments. Studies generally considered positive responses to criteria, such as social or demographic risk factors (unmarried, low level of education, unemployed), ${ }^{59,63}$ drug use during pregnancy, ${ }^{61}$ low birth weight, ${ }^{64}$ or a history of other risk factors (human immunodeficiency virus infection, homelessness, substance use), ${ }^{60}$ among others. Follow-up ranged from 2 to 24 months after delivery, and abuse outcomes were determined by a number of methods.

None of these studies described significantly fewer reports of abuse and neglect in intervention groups compared with control groups, although not all studies were designed for this outcome. ${ }^{63}$ Five of the studies reported other significant intervention effects related to abuse and neglect, such as medical care utilization, parent-child interactions, punishment, stressful life events, parental mental illness, and drug use. ${ }^{59-61,63,64}$

\section{Harms of Screening and Interventions}

No studies were identified that provide data about adverse effects of screening or interventions. False-negative tests may hinder identification of those who are truly at risk. False-positive tests could lead to inappropriate labeling and punitive attitudes. Additional possible harms include psychological distress, escalation of abuse and family tension, loss of personal residence and financial resources, erosion of family structure, loss of autonomy for the victim, and lost time from work. Children could lose contact with established support systems including neighbors, siblings, school contacts, and peer groups.

There has been concern that patients may feel uncomfortable or threatened if asked questions about family violence. Although most women bringing their children to a pediatric emergency department believed screening for family violence was appropriate, many indicated that their willingness to disclose might be affected by fear of being reported to child protective services. ${ }^{69}$ Clinicians in the study indicated that they would feel obligated to report a child to protective services if violence were present in the home.

\section{DISCUSSION}

Detection of child abuse and neglect by clinicians could potentially reduce serious harms to children. Screening for abuse or risk of abuse, however, poses unique challenges. Determining performance characteristics of screening instruments, such as sensitivity and specificity, is difficult because there is no reference standard for detecting actual episodes of abuse. Screening instruments require high sensitivity and specificity, because falsely implicating a parent as an abuser may have serious consequences. For children, mandatory reporting requires that documentation of abuse exists, 
Table 2. Summary of Intervention Studies

\begin{tabular}{|c|c|c|c|c|c|c|c|}
\hline $\begin{array}{l}\text { Author, } \\
\text { Year }\end{array}$ & $\begin{array}{l}\text { No. and } \\
\text { Study } \\
\text { Type }\end{array}$ & Population & $\begin{array}{c}\text { Child's Age } \\
\text { When } \\
\text { Intervention } \\
\text { Ended (Mo) }\end{array}$ & Risk Assessment & $\begin{array}{l}\text { Significant } \\
\text { Decrease } \\
\text { in Abuse } \\
\text { Measures }\end{array}$ & $\begin{array}{l}\text { Other } \\
\text { Significant } \\
\text { Effects* }\end{array}$ & $\begin{array}{l}\text { Quality } \\
\text { Rating }\end{array}$ \\
\hline $\begin{array}{l}\text { Olds } \\
1986^{57} \\
1994^{54} \\
1995^{55} \\
1997^{56}\end{array}$ & $\mathrm{RCT}$ & $\begin{array}{l}\text { Pregnant women, first births } \\
\text { (many teenagers, unmarried, } \\
\text { low social class) small, } \\
\text { semirural county in New } \\
\text { York State }\end{array}$ & 24 & $\begin{array}{l}85 \% \text { had } 1 \text { or more } \\
\text { factors: age }<19 \text { y, } \\
\text { single-parent status, } \\
\text { low income }\end{array}$ & & & Good \\
\hline \multicolumn{8}{|l|}{$\begin{array}{l}\text { Eckenrode, } \\
2000^{58} \\
\text { follow-up }\end{array}$} \\
\hline $2 y$ & 400 & & & & $X(P=.07)$ & $x$ & \\
\hline $3 y$ & 400 & & & & 0 & $x$ & \\
\hline $4 y$ & 56 & & & & 0 & $x$ & \\
\hline $15 y$ & 324 & & & & $x$ & $x$ & \\
\hline $\begin{array}{l}\text { Kitzman, } \\
1997^{63}\end{array}$ & $\begin{array}{l}1,139 \\
\text { RCT }\end{array}$ & $\begin{array}{l}\text { Pregnant, low-income, } \\
\text { minority women, most } \\
\text { teenagers; public obstetric } \\
\text { clinic in Memphis }\end{array}$ & 24 & $\begin{array}{l}\text { First birth with at least } \\
2 \text { factors: unmarried, } \\
12 \text { y of education, } \\
\text { unemployment status }\end{array}$ & NA & $x$ & Fair \\
\hline $\begin{array}{l}\text { Black, } \\
1994^{61}\end{array}$ & $\begin{array}{c}43 \\
\mathrm{RCT}\end{array}$ & $\begin{array}{l}\text { Drug using pregnant women } \\
\text { (majority single, African } \\
\text { American, multiparus, low } \\
\text { education, low income, } \\
\text { history of incarceration, } \\
\text { urban) }\end{array}$ & 18 & $\begin{array}{l}\text { Admitted using cocaine } \\
\text { or heroin during } \\
\text { pregnancy }\end{array}$ & NA & $x$ & Fair \\
\hline $\begin{array}{l}\text { Barth, } \\
\quad 1991^{59}\end{array}$ & $\begin{array}{l}191 \\
\mathrm{RCT}\end{array}$ & $\begin{array}{l}\text { Pregnant women in California } \\
\text { with low income; } 90 \% \text { scored } \\
\text { above mean on Child Abuse } \\
\text { Potential Inventory (CAP) }\end{array}$ & 6 & $\begin{array}{l}\text { Two or more positive } \\
\text { responses to a list of } \\
\text { criteria }\end{array}$ & 0 & NA & Fair \\
\hline $\begin{array}{l}\text { Marcenko, } \\
1994^{60}\end{array}$ & $\begin{array}{l}225 \\
\mathrm{RCT}\end{array}$ & $\begin{array}{l}\text { Pregnant low-income minority } \\
\text { women in Philadelphia }\end{array}$ & 6 & $\begin{array}{l}\text { A history of at least } 1 \\
\text { factor: substance } \\
\text { abuse, homelessness, } \\
\text { domestic violence, } \\
\text { psychiatric illness, } \\
\text { incarceration, HIV } \\
\text { infection, lack of } \\
\text { social support }\end{array}$ & 0 & $x$ & Fair \\
\hline $\begin{array}{l}\text { Brooten, } \\
1986^{64}\end{array}$ & $\begin{array}{c}79 \\
\mathrm{RCT}\end{array}$ & Low birth weight infants & 18 & Weight $<2,200 \mathrm{~g}$ & 0 & $x$ & Fair \\
\hline $\begin{array}{l}\text { Siegel, } \\
1980^{62}\end{array}$ & $\begin{array}{l}331 \\
\mathrm{RCT}\end{array}$ & $\begin{array}{l}\text { Pregnant women; mostly } \\
\text { minority, low education, not } \\
\text { married; North Carolina }\end{array}$ & 12 & None & 0 & 0 & Fair \\
\hline $\begin{array}{l}\text { Cerny, } \\
2001^{67}\end{array}$ & $\begin{array}{c}142 \\
\text { Cohort }\end{array}$ & $\begin{array}{l}\text { Pregnant women at risk for } \\
\text { child abuse or neglect; } \\
\text { Tripler Army Medical Center }\end{array}$ & 12 & $\begin{array}{l}\text { One or more positive } \\
\text { responses to a list of } \\
\text { criteria. }\end{array}$ & 0 & $x$ & Fair-poor \\
\hline $\begin{array}{l}\text { Katzev, } \\
1999^{47}\end{array}$ & $\begin{array}{l}6,921 \\
\text { Cohort }\end{array}$ & $\begin{array}{l}\text { First-birth pregnant women; } \\
\text { Oregon }\end{array}$ & 36 & $\begin{array}{l}\text { HRIS, if high score, then } \\
\mathrm{KFI}\end{array}$ & $x$ & $x$ & Fair-poor \\
\hline $\begin{array}{r}\text { Brayden, } \\
1993^{48}\end{array}$ & $\begin{array}{c}1,082 \\
\mathrm{RCT}\end{array}$ & Pregnant women; Philadelphia & 24 & $\begin{array}{l}\text { Risk factors: frequent } \\
\text { moves, previous } \\
\text { removal of children by } \\
\text { CPS, abusive behavior, } \\
\text { and high scores on } \\
\text { the Life Stress Scale } \\
\text { and Nurture Scale }\end{array}$ & $x$ & NA & Poor \\
\hline $\begin{array}{l}\text { Dawson, } \\
1989^{66}\end{array}$ & $\begin{array}{c}172 \\
\text { Quasi- } \\
\text { experimental }\end{array}$ & $\begin{array}{l}\text { Low-income pregnant women; } \\
\text { Denver }\end{array}$ & 24 & None & $\begin{array}{r}\text { Increased } \\
\text { reports }\end{array}$ & NA & Poor \\
\hline $\begin{array}{l}\text { Flynn, } \\
1999^{68}\end{array}$ & $\begin{array}{l}137 \\
\text { Cohort }\end{array}$ & $\begin{array}{l}\text { Pregnant minority women; } \\
\text { mostly teenagers; Newark }\end{array}$ & 36 & $\begin{array}{l}\text { Based on clinical } \\
\text { judgment }\end{array}$ & 0 & $x$ & Poor \\
\hline $\begin{array}{l}\text { Gray, } \\
197965\end{array}$ & $\begin{array}{l}150 \\
\mathrm{RCT}\end{array}$ & Pregnant women; Denver & 36 & $\begin{array}{l}\text { Based on clinical } \\
\text { judgment }\end{array}$ & $\begin{array}{r}\text { Increased } \\
\text { reports }\end{array}$ & $x$ & Poor \\
\hline
\end{tabular}

$\mathrm{RCT}=$ randomized controlled trial; $\mathrm{X}=$ significant relationship; $0=$ studied but not significant; $\mathrm{NA}=$ not studied; HIV $=$ human immunodeficiency virus; HRIS $=$ Hawaii Risk Indicator Scale; KFI = Kempe Family Stress Inventory; CPS = Child Protective Services.

*Other outcomes include injury, poisoning, hospitalizations, child development level, and others. 
but reported abuse likely captures only a fraction of all cases. In a recent survey of nurses and physicians, $71 \%$ of respondents rated the identification of maltreatment as rather difficult or difficult. ${ }^{70}$ Work pressure, unfamiliarity, and awkwardness were cited as barriers.

Existing instruments to detect child abuse are not designed for direct administration to the child, missing opportunities to screen older children in the context of usual health care. Screening for abuse in the primary care setting can involve a variety of techniques, including physical examination as well as questionnaires. History from the child has been stated as the most important diagnostic feature in determining child sexual abuse. ${ }^{71}$ Findings during a routine physical examination suggestive of abuse and neglect, such as burns, bruises, and repeated suspect traumatic injury, have been described. ${ }^{39,72}$ Many professional medical organizations, including the American Academy of Pediatrics, the American Medical Association, and the American Academy of Family Physicians, recommend that physicians remain alert for the signs and symptoms of child abuse and neglect in the medical visit.

Even if current screening methods correctly identified children at risk of abuse, optimal interventions are not clearly established or widely available. Studies of interventions for prevention of child abuse focused on the prenatal, postpartum, and early childhood periods. ${ }^{73}$ Both the US Task Force on Community Preventive Services ${ }^{41}$ and the Canadian Task Force on Preventive Health Care ${ }^{42}$ recommend this service. Interventions for older children have not yet been shown to be effective.

There are many gaps in the evidence for screening children for abuse, and future research should address these needs. Definitions and measures of abuse, neglect, severity, and chronicity need to be standardized across studies. Existing screening instruments require more testing and validation in various health care settings, as well as modification of those that are too long or complex for medical practice. Instruments require validation in languages other than English.

Studies need to consider the influence of observer or surveillance bias. ${ }^{26,41,55}$ In studies of child abuse, families in the intervention group are often observed more closely than those in the control group and may be more likely to have abuse detected. ${ }^{65,66}$ Results could be misrepresented. Interventions are dissimilar between studies and often inadequately described. Programs that deviate from tested models may have different results.

Screening and intervention studies are generally confined to certain high-risk populations while overlooking others, such as special cultural groups and military families. Broader applications would show whether results are generalizable. More research is required to better understand pregnancy-related violence, such as the course of violence during pregnancy and postpartum, health implications, the role of violence on reproductive decision making, and determination of what screening and intervention strategies are most effective for this population. ${ }^{73}$

Evaluations of the feasibility of screening procedures and interventions in health care settings must consider costs, time, resources, clinician consistency, barriers, and patient compliance. Evaluations of strategies enlisting health systems and community programs are needed. Studies of the effectiveness of treatment programs for abused victims, as well as for perpetrators, would provide needed evidence that identification and intervention can lead to improved health outcomes. These outcomes should include not only measures of reduced violence, but also associated health outcomes, such as improved quality of life, mental health, ${ }^{74}$ social support, self-esteem, productivity, and others.

Despite the prevalence of child abuse and neglect and its impact on health, there are few studies providing data on its detection and management to guide clinicians. As a result, clinicians have difficulty fulfilling their role in prevention and treatment of the harms of family violence.

To read commentaries or to post a response to this article, see it online at http://www.annfammed.org/cgi/content/full/2/2/161.

Key words: Domestic violence/prevention and control; child abuse; child neglect; review, academic; evidence-based medicine

Submitted June 27, 2003; submitted, revised,November 12, 2003; accepted November 30, 2003.

Funding support: This study was conducted by the Oregon Evidencebased Practice Center under contract to the Agency for Healthcare Research and Quality Contract \#290-97-0018, Task Order Number 2, Rockville, Md, to support the work of the USPSTF.

Disclaimer: The authors of this article are responsible for its contents, including clinical or treatment recommendations. No statement in this article should be construed as an official position of the Agency for Healthcare Research and Quality or the US Department of Health and Human Services.

Acknowledgments: Agency staff and USPSTF members participated in the initial design of the study and reviewed interim analyses and the final manuscript. Additional reports were distributed for review to content experts and revised accordingly before preparation of this manuscript. The authors thank members of the USPSTF and reviewers of the evidence report for their contributions to this project. We are grateful to Kim Villemyer and Miranda Norbraten for their assistance with preparation of this manuscript.

Requests for single reprints: Reprints are available from the Agency for Healthcare Research and Quality Web site (http://www.preventiveservices. ahrq.gov) and through the Agency for Healthcare Research and Quality Publications Clearinghouse (telephone, 800-358-9295). 


\section{References}

1. Child Abuse Prevention and Treatment Act Amendments (CAPTA) of 1996. Pub L No. 104-235; 1996.

2. Sedlak AJ, Broadhurst DD, for the US Department of Health and Human Services. Third National Incidence Study of Child Abuse and Neglect: Final Report. Washington, DC: US Department of Health and Human Services, National Center on Child Abuse and Neglect; 1996. Publication NIS-3.

3. US Department of Health and Human Services. Child Maltreatment 1999: Reports from the States to the National Child Abuse and Neglect Data System. Washington, DC: US Department of Health and Human Services; 2001.

4. Fergusson DM, Horwood LJ, Woodward LJ. The stability of child abuse reports: a longitudinal study of the reporting behaviour of young adults. Psychol Med. 2000;30:529-544.

5. Felitti VJ, Anda RF, Nordenberg D, et al. Relationship of childhood abuse and household dysfunction to many of the leading causes of death in adults. The Adverse Childhood Experiences (ACE) Study. Am J Prev Med. 1998;14:245-258.

6. Brown J, Cohen $\mathrm{P}$, Johnson J. A longitudinal analysis of risk factors of child maltreatment: findings of a 17-year prospective study of officially recorded and self-reported child abuse and neglect. Child Abuse Negl. 1998;22:1065-1078.

7. Cadzow SP, Armstrong KL, Fraser JA. Stressed parents with infants: reassessing physical abuse risk factors. Child Abuse Negl. 1999;23: 845-853.

8. Kotch JB, Browne DC, Ringwalt $C L$, et al. Risk of child abuse or neglect in a cohort of low-income children. Child Abuse Negl. 1995; 19:1115-1130.

9. McGuigan WM, Pratt CC. The predictive impact of domestic violence on three types of child maltreatment. Child Abuse Negl. 2001;25:869-883.

10. Mammen OK, Kolko DJ, Pilkonis PA. Negative affect and parental aggression in child physical abuse. Child Abuse Negl. 2002;26:407424.

11. Dubowitz H. Preventing child neglect and physical abuse: a role for pediatricians. Pediatr Rev. 2002;23:191-196.

12. Coker AL, Smith PH, Thompson MP, McKeown RE, Bethea L, Davis KE. Social support protects against the negative effects of partner violence on mental health. J Womens Health Gend Based Med. 2002;11:465-476.

13. Diaz A, Simantov E, Rickert VI. Effect of abuse on health: results of a national survey. Arch Pediatr Adolesc Med. 2002;156:811-817.

14. Dube SR, Anda RF, Felitti VJ, Chapman DP, Williamson DF, Giles WH. Childhood abuse, household dysfunction, and the risk of attempted suicide throughout the life span: findings from the Adverse Childhood Experiences Study. JAMA. 2001;286:3089-3096.

15. Anda RF, Chapman DP, Felitti VJ, et al. Adverse childhood experiences and risk of paternity in teen pregnancy. Obstet Gynecol. 2002; 100:37-45.

16. Silverman JG, Raj A, Mucci LA, Hathaway JE. Dating violence against adolescent girls and associated substance use, unhealthy weight control, sexual risk behavior, pregnancy, and suicidality. JAMA. 2001;286:572-579.

17. Osofsky JD, Wewers S, Hann DM, Fich AC. Chronic community violence: what is happening to our children? Psychiatry. 1993;56:36-45.

18. Shakoor BH, Chalmers D. Co-victimization of African-American children who witness violence: effects on cognitive, emotional and behavioral development. J Natl Med Assoc. 1991;83:233-238.

19. Lansford JE, Dodge KA, Pettit GS, Bates JE, Crozier J, Kaplow J. A 12 year prospective study of the long-term effects of early child physical maltreatment on psychological, behavioral, and academic problems in adolescence. Arch Pediatr Adolesc Med. 2002;156:824-830.
20. Campbell JC, Lewandowski LA. Mental and physical health effects of intimate partner violence on women and children. Psychiatr Clin North Am. 1997;20:353-374.

21. Campbell DW, Sharps PW, Gary FA, Campbell JC, Lopez LM. Intimate partner violence in African American women. Online J Issues Nurs. 2002;7:5.

22. Maxfield M, Widom C. The cycle of violence, revisited 6 years later. Arch Adolesc Med. 1996;50:390-395.

23. Garbarino J, Kostelny DN. What children can tell us about living in danger. Am Psychol. 1991;46:376-383.

24. Durant RH, Pendergrast RA, Cadenhead C. Exposure to violence and victimization and fighting behavior by black urban adolescents. J Adolesc Health. 1994;15:311-318.

25. Coid J, Petruckevitch A, Feder G, Chung W, Richardson J, Moorey S. Relation between childhood sexual and physical abuse and risk of revictimisation in women: a cross-sectional survey. Lancet. 2001;358: 450-454.

26. Roberts SJ. The sequelae of childhood sexual abuse: a primary care focus for adult female survivors. Nurse Pract. 1996;21(12 Pt 1):42, 45, 49-52.

27. Kershner M, Long D, Anderson JE. Abuse against women in rural Minnesota. Public Health Nurs. 1998;15:422-431.

28. Kantor GK, Straus MA. Substance abuse as a precipitant of wife abuse victimizations. Am J Drug Alcohol Abuse. 1989;15:173-189.

29. American Medical Association Council on Scientific Affairs. Diagnostic and treatment guidelines concerning child abuse and neglect. JAMA. 1985;254:796-800.

30. Aravanis SC, Adelman RD, Breckman R, et al. Diagnostic and treatment guidelines on elder abuse and neglect. Arch Fam Med. 1993;2: 371-388.

31. Child Abuse and Neglect: State Statutes Series, Current Trends in Child Maltreatment Reporting Laws. Washington, DC: US Department of Health and Human Services, Administration for Children and Families; 1999.

32. Joint Commission on Accreditation of Healthcare Organizations. Accreditation Manual for Hospitals. Vol 1-Standards. Oakbrook Terrace, IL: Joint Commission on Accreditation of Healthcare Organizations; 1992.

33. Borowsky IW, Ireland M. Parental screening for intimate partner violence by pediatricians and family physicians. Pediatrics. 2002;110: 509-516.

34. Chamberlain L, Perham-Hester KA. Physicians' screening practices for female partner abuse during prenatal visits. Matern Child Health J. 2000;4:141-148.

35. Chamberlain L, Perham-Hester KA. The impact of perceived barriers on primary care physicians' screening practices for female partner abuse. Women Health. 2002;35:55-69.

36. Glass N, Dearwater S, Campbell J. Intimate partner violence screening and intervention: data from eleven Pennsylvania and California community hospital emergency departments. J Emerg Nurs. 2001;27: 141-149.

37. Erickson MJ, Hill TD, Siegel RM. Barriers to domestic violence screening in the pediatric setting. Pediatrics. 2001;108:98-102.

38. Rodriguez MA, Sheldon WR, Bauer HM, Perez-Stable EJ. The factors associated with disclosure of intimate partner abuse to clinicians. J Fam Pract. 2001;50:338-344.

39. US Preventive Services Task Force. Guide to Clinical Preventive Services. 2nd ed. Washington, DC: US Depatment of Health and Human Services; 1996.

40. Nelson $H$, Nygren $P$, Mclnerney $Y$, Klein J. Screening women and elderly adults for family and intimate partner violence. A review of the evidence for the US Preventive Services Task Force. Ann Intern Med. 2004;140:387-396. 
41. Task Force on Community Preventive Services. First reports evaluating the effectiveness of strategies for preventing violence: early childhood home visitation. MMWR. 2003;52(RR14):1-9.

42. MacMillan HL, Canadian Task Force on Preventive Health C. Preventive health care, 2000 update: prevention of child maltreatment. Can Med Assoc J. 2000;163:1451-1458.

43. Chalk R, King PA. Violence In Families: Assessing Prevention and Treatment Programs. Washington, D.C.: Commission on Behavioral and Social Sciences and Education National Research Council and Institute of Medicine; 1998.

44. Stevens-Simon C, Nelligan D, Kelly L. Adolescents at risk for mistreating their children. Part I: prenatal identification. Child Abuse Negl. 2001;6:737-751.

45. Center on Child Abuse Prevention Research. Intensive home visitation: A randomized trial, follow-up, and risk assessment study of Hawaii's Healthy Start program. Final report prepared for the National Center on Child Abuse and Neglect. Chicago: National Committee to Prevent Child Abuse (NCCAN Grant \#90-CA-1511); 1996.

46. Center on Child Abuse Prevention Research. Targeting Prevention services: The use of risk assessment in Hawaii's Healthy Start Program. Executive summary prepared for the National Center on Child Abuse and Neglect. Chicago: National Committee to Prevent Child Abuse 1996. NCCAN Grant \#90-CA-1511.

47. Katzev A, Pratt C, Henderson T, McGuigan W. Oregon's Healthy Start Effort: 1997-98 Status Report. Corvallis, OR; 1999.

48. Brayden $\mathrm{R}$, Altemeier W, Dietrich $\mathrm{M}$, et al. A prospective study of secondary prevention of child maltreatment. J Pediatr. 1993;122:511-516.

49. Anderson CL. The parenting profile assessment: screening for child abuse. Appl Nurs Res. 1993;6:31-38.

50. Leventhal JM, Pew MC, Berg AT, Garber RB. Use of health services by children who were identified during the postpartum period as being at high risk of child abuse or neglect. Pediatrics. 1996;97:331-335.

51. Duggan A, Windham A, McFarlane E, Fuddy L, Rohde C, Buchbinder $\mathrm{S}$, et al. Hawaii's healthy start program of home visiting for at-risk families: evaluation of family identification, family engagement, and service delivery. Pediatrics. 2000; 105:250-259.

52. Korfmacher J. The Kempe Family Stress Inventory: a review. Child Abuse Negl. 2000;24:129-140.

53. Murphy S, Orkow B, Nicola RM. Prenatal prediction of child abuse and neglect: a prospective study. Child Abuse Negl. 1985;9:225-235.

54. Olds DL, Henderson CR, Kitzman H. Does prenatal and infancy nurse home visitation have enduring effects on qualities of parental caregiving and child health at 25 to 50 months of life? Pediatrics. 1994;93:89-98.

55. Olds D, Henderson CR, Kitzman H, Cole R. Effects of prenatal and infancy nurse home visitation on surveillance of child maltreatment. Pediatrics. 1995;95:365-372.

56. Olds DL, Eckenrode J, Henderson CR, et al. Long-term effects of home visitation on maternal life course and child abuse and neglect. Fifteenyear follow-up of a randomized trial. JAMA. 1997;278:637-643.

57. Olds DL, Henderson CR, Jr, Chamberlin R, Tatelbaum R. Preventing child abuse and neglect: a randomized trial of nurse home visitation. Pediatrics. 1986;78:65-78.
58. Eckenrode J, Ganzel B, Henderson CR, et al. Preventing child abuse and neglect with a program of nurse home visitation: the limiting effects of domestic violence. JAMA. 2000;284:1385-1391.

59. Barth RP. An experimental evaluation of in-home child abuse prevention services. Child Abuse Negl. 1991;15:363-375.

60. Marcenko MO, Spence M. Home visitation services for at-risk pregnant and postpartum women: a randomized trial. Am J Orthopsychiatry. 1994;64:468-478.

61. Black MM, Nair P, Kight C, Wachtel R, Roby P, Schuler M. Parenting and early development among children of drug-abusing women: effects of home intervention. Pediatrics. 1994;94.

62. Siegel E, Bauman KE, Schaefer ES, Saunders MM, Ingram DD. Hospital and home support during infancy: impact on maternal attachment, child abuse and neglect, and health care utilization. Pediatrics. 1980;66:183-190.

63. Kitzman H, Olds D, Henderson C. Effect of prenatal and infancy home visitation by nurses on pregnancy outcomes, childhood injuries, and repeated childbearing: a randomized controlled trial. JAMA. 1997;278:644-652.

64. Brooten D, Kumar S. A randomized controlled trial of early hospital discharge and home follow-up of very-low-birth weight infants. $N$ Engl J Med. 1986;315:934-939.

65. Gray JD, Cutler CA, Dean JG, Kempe CH. Prediction and prevention of child abuse. Semin Perinatol. 1979:3:85-90.

66. Dawson P, Van Doorninck WJ, Robinson JL. Effects of home-based, informal social support on child health. Dev Behav Pediatr. 1989;10: 63-67.

67. Cerny JE, Inouye J. Utilizing the child abuse potential inventory in a community health nursing prevention program for child abuse. $J$ Commun Health Nurs. 2001;18:199-211.

68. Flynn L. The adolescent parenting program: improving outcomes through mentorship. Public Health Nurs. 1999;16:182-189.

69. Dowd MD, Kennedy C, Knapp JF, Stallbaumer-Rouyer J. Mothers' and health care providers' perspectives on screening for intimate partner violence in a pediatric emergency department. Arch Pediatr Adolesc Med. 2002;156:794-799.

70. Paavilainen E, Merikanto J, Astedt-Kurki P, Laippala P, Tammentie T, Paunonen-IImonen M. Identification of child maltreatment while caring for them in a university hospital. Int J Nurs Stud. 2002;39:287294.

71. Heger A, Ticson L, Velasquez O, Bernier R. Children referred for possible sexual abuse: medical findings in 2384 children. Child Abuse Negl. 2002;26:645-659

72. Johnson PA, Owens RG, Dewey ME, Eisenberg NE. Professionals' attributions of censure in father-daughter incest. Child Abuse Negl. 1990; 14:419-428.

73. Martin S, Mackie L, Kupper L, Buescher P, Moracco K. Physical abuse of women before, during, and after pregnancy. JAMA. 2003:285:1581-1584.

74. Stein B, Jaycox L, Kataoka S, et al. A mental health intervention for schoolchildren exposed to violence. JAMA. 2003;290:603-611. 